\title{
PENDIRIAN BANK TANPA IZIN MELAKUKAN USAHA PERBANKAN (SHADOW BANKING) DALAM PERSPEKTIF HUKUM ISLAM
}

\author{
NURFYANA NARMIA SARI, DUDUNG ABDULLAH \\ Fakultas Syariah dan Hukum Universitas Islam Negeri Alauddin Makassar
}

\begin{abstract}
Abstrak
Penerapan hukum pidana tidak terlepas dari bukti-bukti yang terdapat di dalam putusan, selain mengacu ke putusan, hakim juga menerapkan apa yang telah tertuang di dalam Undang-undang tentang pelanggaran bank, salah satu penerapan hukum pidana pada kasus Nomor 222/Pid.Sus/2018/Pn.Mks yaitu terdakwa dinyatakan telah melanggar Pasal 46 ayat 1 Jo. Pasal 16 Undang-Undang Nomor 7 Tahun 1992 tentang perbankan. Dengan adanya bukti-bukti, dakwaan jaksa penuntut dan keterangan terdakwa. Sehingga penerapan hukumnya hanya berdasarkan Undang-Undang dan surat keputusan. Menjatuhkan pidana terhadap terdakwa dengan pidana penjara selama 7 (tujuh) tahun dikurangi penahanan yang telah dijalani, dengan perintah agar terdakwa tetap ditahan, denda sebesar Rp. 10.000.000.000,00 (sepuluh miliar rupiah) subsidair 6 bulan penjara. Sedangkan dalam pandangan Hukum Islam pendirian bank tanpa izin melakukan usaha perbankan (Shadow Banking) yaitu: haram zatnya, haram selain zatnya, tidak sah (lengkap) akadnya, dan termasuk Syirkah Amwāl (kongsi dana) dibolehkan dalam Islam tetapi bisa menjadi tidak sah karena tidak memiliki izin.
\end{abstract}

Kata Kunci : Pendirian Bank, Tanpa Izin Usaha, Hukum Islam.

\begin{abstract}
The application of criminal law is inseparable from the evidence contained in the decision, in addition to referring to the decision, the judge also applies what has been stated in the Law on bank violations, one of the applications of criminal law in case Number 222/Pid.Sus/2018/Pn.Mks ie the defendant is declared to have violated Article 46 paragraph 1 Jo. Article 16 of Law Number 7 of 1992 concerning banking. With the evidence, the prosecutor's indictment and the defendant's statement. So that the application of the law is only based on laws and decrees. Sentencing the defendant to imprisonment for 7 (seven) years less the detention that has been served, with the order that the defendant remain detained, a fine of Rp. 10,000,000,000.00 (ten billion rupiah) subsidiary 6 (six) months in prison. Whereas in view of Islamic Law the establishment of a bank without a license to conduct banking (Shadow Banking) business, namely: illicit substances, illicit other than substances, illegitimate (complete) contracts, and including Syirkah Amwāl (joint venture funds) are permitted in Islam but can be invalid because they aren't legal have permission.
\end{abstract}

Keywords: Establishment of Bank, Without Business License, Islamic Law. 


\section{A. PENDAHULUAN}

Dewasa ini kejahatan pidana telah marak terjadi baik di kalangan masyarakat menengah ke bawah hingga masyarakat menengah ke atas. Bukan hanya sekali atau dua kali, kejahatan bank sudah marak terjadi sehingga menyita perhatian masyarakat. Seperti pada kasus pendirian bank tanpa izin (bank gelap) yang menghimpun dana masyarakat termasuk tindak pidana khusus karena tindak pidana perbankan banyak diatur di dalam Undang-Undang Republik Indonesia.

Pendirian bank menurut Undang-undang Nomor 10 Tahun 1998 dapat memilih badan hukum seperti, Perseroan Terbatas, Koperasi, atau Perusahaan Daerah. Dalam Undang-undang Nomor 10 Tahun 1998, pendirian bank umum dapat di lakukan oleh warga negara asing atau badan hukum asing dan cara bermitra dengan warga negara Indonesia dan badan hukum Indonesia, tanpa ada pembatasan maksimum jumlah kepemilikan bagi pihak asing. ${ }^{1}$

Pengaturan kegiatan usaha perbankan sebagaimana diatur dalam Undang-undang Nomor 7 Tahun 1992 dilaksanakan oleh Bank Indonesia bekerja sama dengan Departemen Keungan. Sedangkan pengawasan dan pembinaan teknis operasional perbankan dilakukan oleh Bank Indonesia. ${ }^{2}$ Praktik bank yang dilakukan tanpa izin pada dasarnya tidak diatur dalam Undang-undang yang berlaku di Indonesia. Melakukan praktik bank tanpa adanya izin usaha dapat disebut atau dikategorikan "Bank Gelap", bank gelap merupakan badan yang melakukan kegiatan penghimpunan dana masyarakat tanpa izin usaha melakukan kegiatan tersebut dari pimpinan Bank Indonesia. ${ }^{3}$ Setiap pihak yang melakukan kegiatan menghimpun dana dari masyarakat dalam bentuk simpanan wajib terlebih dahulu memperoleh izin usaha sebagai Bank Umum atau Bank Perkreditan Rakyat dari pimpinan Bank Indonesia. Perizinan usaha Bank Umum dan Bank Perkreditan Rakyat yang dapat diajukan dengan kewajiban untuk memenuhi persyaratan sekurang-kurangnya tentang susunan organisasi dan kepengurusan, permodalan, kepemilikan, keahlian di bidang perbankan, dan kelayakan rencana kerja. ${ }^{4}$

Kasus pencucian uang banyak menyita perhatian masyarakat karena sudah marak terjadi dan dewasa ini pendirian bank tanpa izin (bank gelap) kurang menyita perhatian masyarakat padahal bank gelap termasuk tindak pidana yang merugikan masyarakat. Pendirian bank tanpa izin biasanya tidak berbentuk seperti bank pada umumnya tetapi pendirian bank tanpa izin biasanya berbentuk koperasi atau Multi Level Marketing $(M L M)$ yang menggiurkan masyarakat untuk menjadi member, namun demikian pendirian koperasi atau Multi Level Marketing (MLM) tanpa izin merupakan suatu pelanggaran pidana karena menghimpun dana masyarakat menggunakan buku tabungan tanpa izin dari pihak Bank Indonesia. Jika pendirian bank tanpa izin terus menurus dilakukan maka akan mengakibatkan kerugian yang besar terhadap pihak bank dan akan berdampak pada Negara karena bisa saja masyarakat tidak lagi menjadi nasabah resmi bank karena masyarakat telah tergiur dengan iming-iming keuntungan yang besar jika bergabung dengan koperasi atau $M L M$. Tetapi tidak semua koperasi dan $M L M$ tidak

${ }^{1}$ Darmono Saputro, Siswandi, Banking and Non Banking, (Jakarta: Lentera Ilmu Cendikia, 2010), h. 39.

${ }^{2}$ Darmono Saputro, Siswandi, Banking and Non Banking, h. 40.

${ }^{3}$ Direktori Institusi Perbankan http://www.bi.go.id/id/publikasi/dpl/default.aspx.

${ }^{4}$ Junaidi, Pengaturan Hukum Perbankan Syari'ah di Indonesia, (Malang: UIN-Malang Press, 2009), h. 72. 
memiliki izin hanya saja ada beberapa oknum yang kurang bertanggung jawab mendirikan usaha perbankan tanpa izin dari Bank Indonesia. Menghimpun dana dari masyarakat tanpa izin juga termasuk riba karena tidak adanya akad antara pimpinan bank dengan pelaku.

Jumhur ulama mensyaratkan bahwa "supaya akad bisa terbentuk objek akad harus wujud pada waktu dilakukannya transaksi terhadap sesuatu yang ma'duum (belum berwujud, fiktif) ${ }^{5}$ seperti penghimpunan dana masyarakat yang menggunakan sistem aplikasi dengan iming-iming menghasilkan uang".

Berdasarkan Pasal 46 ayat 1 Undang-Undang Nomor 10 Tahun 1998 tentang perubahan atas Undang-Undang Nomor 7 Tahun 1992 tentang perbankan berbunyi "barang siapa menghimpun dana dari masyarakat dalam bentuk simpanan tanpa izin usaha dari Pimpinan Bank Indonesia sebagaimana dimaksud dalam Pasal 16, diancam dengan pidana penjara sekurang-kurangnya 5 (lima) tahun dan paling lama 15 (lima belas) tahun serta denda sekurang-kurangnya Rp. 10.000.000.000.00 (sepuluh miliar rupiah) dan paling banyak 200.000.000.000.00 (dua ratus miliar rupiah). ${ }^{6}$

Berdasarkan kitab Undang-Undang Hukum Pidana, terdakwa tersebut dapat berpotensi dikenakan Pasal perihal penggelapan (Pasal 372 KUHP) dengan ancaman sanksi pidana penjara paling lama empat tahun dan penggelapan dalam jabatan (Pasal 374 KUHP) dengan ancaman pidana penjara paling lama empat tahun.

Penghimpunan dana tanpa izin seharusnya ditindak lanjuti karena dapat merugikan masyarakat hingga merugikan Negara, penghimpunan dana masyarakat menggunakan tabungan giro termasuk percampuran harta yang satu dengan yang lainnya sehingga tidak bisa lagi dibedakan berapa jumlahnya. Pendirian bank tanpa izin (shadow banking) termasuk jarimah tazir hal tersebut telah ditetapkan oleh pemerintah, namun di dalam hukum Islam pendirian bank tanpa izin/menghimpun dana masyarakat tanpa izin termasuk penipuan karena meraup keuntungan dana masyarakat dengan iming-iming keuntungan yang besar melalui sistem aplikasi. Praktik tersebut menjanjikan keuntungan investasi yang tidak wajar, baik berupa pendapatan dan imbal hasil, baik dalam bentuk persentase maupun dalam bentuk jumlah nominal tanpa kejelasan.

Secara realitas masih banyak pelaku yang menghimpun dana masyarakat menggunakan giro/tabungan tanpa izin dari pihak bank sehingga harus ditindak lanjuti, tentu saja hal tersebut akan berdampak buruk bagi Negara maupun masyarakat. Hal ini memungkinkan untuk melakukan penelitian terhadap analisis yuridis yang dimaksud. Hal penting yang lainnya adalah Negara Indonesia tidak hanya mengenal hukum positif tetapi Negara Indonesia juga mengenal hukum Islam. Walaupun hukum Islam tidak dianut oleh Negara Indonesia tetapi hukum Islam kadang berkesinambungan dengan hukum positif. Dalam menghadapi masalah tindak pidana pendirian bank tanpa izin (shadow banking) maka perlu pengkajian mendalam mengenai bagaimana hukum Islam dan hukum positif menanggapi hal tersebut.

\footnotetext{
${ }^{5}$ Wahbah Az-Zuhaili, Fiqih Islam Wa Adilllatuhu jilid 7 , Terj. Abdul Hayyie al-Kattani, (Jakarta: Gema Insani, 2011), h. 9.

${ }^{6}$ Republik Indonesia, Undang-Undang Nomor 10 Tahun 1998 tentang perubahan atas UndangUndang Nomor 7 Tahun 1992 tentang perbankan (t.d), h.24.
} 


\section{B. METODE PENELITIAN}

Jenis penelitian ini adalah penelitian deskriptif kualitatif lapangan (field research) dengan pendekatan penelitian yaitu: yuridis normatif. Adapun sumber data penelitian ini adalah Hakim Pengadilan Negeri Makassar yang menangani perkara ini. Metode pengumpulan data yang dilakukan melalui observasi, wawancara, dokumentasi, dan studi kepustakaan. Teknik pengolahan dan analisis data dilakukan dengan melalui empat tahap yaitu: reduksi data, klarifikasi data, penyajian data, dan penarikan kesimpulan yang diolah dengan teknik analisis data menggunakan metode analisis kualitatif.

\section{PEMBAHASAN}

\section{Dasar Pertimbangan Hakim dalam Menjatuhkan Putusan pada Kasus Putusan} 222/Pid.Sus/2018/PN.Mks.

Hukum merupakan salah satu bentuk peringatan kepada masyarakat agar tidak melakukan kejahatan tetapi banyak yang menganggap hukum hanya main-main saja sehingga banyak masyarakat yang tidak takut melakukan tindak pidana seperti penipuan, perampokan, pencurian dan lain-lain. Tetapi dalam perkembangannya, hukum pidana ternyata tidak hanya mengatur masalah kejahatan tetapi hukum pidana juga mengatur masalah pelanggaran seperti pelanggaran lalu lintas. "Hakim sebagai penegak hukum dan keadilan juga wajib menggali, mengikuti, dan memahami nilai-nilai hukum yang hidup dalam masyarakat, hakim merupakan perumus dan penggali dari nilai-nilai hukum yang hidup dikalangan rakyat, untuk itu, harus terjun ketengah-tegah masyarakat untuk mengenal, merasakan, dan mampu menjalani perasaan hukum dan rasa keadilan yang hidup dalam masyarakat. Dengan demikian, hakim dalam memberikan putusan yang sesuai dengan hukum dan rasa keadilan masyarakat". 7

Dalam Undang-Undang Nomor 48 tahun 2009 tentang kekuasaan kehakiman pada Pasal 50 ayat (1) disebutkan putusan pengadilan selain harus memuat alasan dan dasar putusan, juga memuat Pasal dari peraturan perundang-undangan yang bersangkutan atau sumber hukum tak tertulis yang dijadikan dasar untuk mengadili. Berhubungan dengan kebebasan hakim, perlu pula dipaparkan tentang posisi hakim yang tidak memihak (impartial judge). Istilah tidak memihak disini haruslah diartikan tidak harfiah, karena dalam menjatuhkan putusannya hakim harus memihak kepada yang benar, hakim tidak memihak diartikan tidak berat sebelah dalam pertimbangan dan penilaiannya. ${ }^{8}$ Hakim dalam menjatuhkan putusannya baik itu berupa putusan pemidanaan yang lain sebagainya. Pertimbangan mengenai hal-hal yang memberatkan dan meringankan terdakwa ini diatur dalam Pasal 197 huruf d dan 197 huruf f KUHAP Dalam Pasal 197 huruf d berbunyi, "Pertimbangan yang disusun secara ringkas mengenai fakta dan keadaan beserta alat pembuktian yang diperoleh dari pemeriksaan disidang yang menjadi dasar penentuan kesalahan terdakwa".

Sebagai penegak hukum, hakim mempunyai tugas dibidang yudisial, yaitu menerima, memeriksa, memutuskan dan menyelesaikan setiap perkara yang diajukan kepadanya. Seorang hakim yang menerima perkara harus memeriksa dengan teliti

\footnotetext{
${ }^{7}$ Aris Gunawan, S.H, MH, Hakim Pengadilan Negeri Makassar,Wawancara, Makassar, 21 Mei 2019.

${ }^{8}$ Andi Hamzah, Hukum Acara Pidana Indonesia, (Jakarta: Sinar Grafika, 2008), h. 106.

${ }^{9}$ Kitab Undang-Undang Hukum Acara Pidana, h. 69
} 
sehingga hakim tidak diragukan lagi jadi seorang hakim harus jujur dalam memutuskan disaat menyelesaikan perkara karena hakim dianggap sebagai wakil tuhan.

Menurut penelitian yang dilakukan di Pengadilan Negeri Makassar ditemukan adanya putusan hakim yang mempertimbangkan hal memberatkan bagi terdakwa terdapat dalam putusan 222/Pid.Sus/2018/PN.Mks.

Pertimbangan Hakim dalam Penjatuhan Putusan Penerapan hukum positif oleh hakim harus mengindahkan nilai-nilai dan rasa keadilan yang hidup dalam masyarakat dengan sebaik-baiknya, sehingga putusan yang dihasilkan oleh hakim bisa diterima dengan ikhlas oleh para pihak, untuk itu tentunya hakim dalam menjatuhkan pidana harus dalam rangka menjamin tegaknya kebenaran, keadilan dan kepastian hukum bagi seseorang. ${ }^{10}$ Jadi hakim sebelum menjatuhkan pidana juga wajib memperhatikan dua hal pokok yaitu hal-hal yang memberatkan dan meringakan pidana. Faktor-faktor yang meringankan merupakan refleksi sifat terbaik dari terdakwa pada saat persidangan berlangsung, dan faktor yang memberatkan dinilai sebagai sifat yang jahat dari terdakwa. Pertimbangan hakim yang demikian dapat mengacu pada Pasal 5 ayat (1) yaitu hakim dan hakim konstitusi wajib menggali, mengikuti dan memahami nilai-nilai hukum dan rasa keadilan yang hidup dalam masyarakat. Dan dalam Pasal 8 ayat (2) juga disebutkan dalam mempertimbangkan ringannya pidana, hakim wajib memperhatikan pula sifat yang baik dan jahat dari terdakwa.

Pertimbangan yang bersifat yuridis adalah pertimbangan hakim yang didasarkan pada fakta-fakta yuridis yang terungkap didalam persidangan dan oleh undang-undang telah ditetapkan sebagai hal yang harus dimuat didalam putusan. Adapun pertimbangan hakim yang digolongkan sebagai pertimbangan yuridis secara sistematis akan diuraikan sebagai berikut:

1. Dakwaan Jaksa Penuntut Umum

Dakwaan ini merupakan dasar hukum acara pidana karena berdasarkan itulah pemeriksaan persidangan dilakukan. Dakwaan selain berisikan identitas terdakwa juga memuat uraian tindak pidana yang didakwakan dengan menyebut waktu dan tempat tindak pidana itu dilakukan. Selain itu dakwaan penuntut umum digunakan oleh hakim sebagai bahan pertimbangan pengadilan dalam menjatuhkan putusan. Dengan demikian dapatlah dikatakan bahwa pengadilan dalam menjatuhkan putusan senantiasa menjadikan surat dakwaan sebagai suatu bahan pertimbangan. Perumusan dakwaan didasarkan atas hasil pemeriksaaan, dan dalam putusan Nomor 222/Pid.Sus/2018/Pn.Mks. Dalam putusan ini jaksa penuntut umum menuntut terdakwa dengan dakwaan tunggal yaitu melanggar Pasal 46 ayat (1) Jo Pasal 16 Undang-Undang Republik Indonesia Nomor 7 Tahun 1992 tentang perbankan sebagaimana yang telah diubah Undang-Undang Republik Indonesia Nomor 10 Tahun 1998 yang berbunyi sebagai berikut:

"barang siapa menghimpun dana dari masyarakat dalam bentuk simpanan tanpa izin usaha dari Pimpinan Bank Indonesia sebagaimana dimaksud dalam Pasal 16, diancam dengan pidana penjara sekurang-kurangnya 5 (lima) tahun dan paling lama 15 (lima belas) tahun serta denda sekurang-kurangnya Rp. 10.000.000.000.00

${ }^{10}$ Bambang Waluyo, Pidana dan Pemidanaan, (Jakarta: Sinar grafika, 2004), h. 33. 
(sepuluh miliar rupiah) dan paling banyak 200.000.000.000.00 (dua ratus miliar rupiah). ${ }^{11}$

Menjatuhkan pidana terhadap terdakwa dengan pidana penjara selama 7 (tujuh) tahun dikurangi penahanan yang telah dijalani, dengan perintah agar terdakwa tetap ditahan, denda sebesar Rp. 10.000.000.000,00 (sepuluh miliar rupiah) subsidair 6 (enam) bulan penjara. Bahwa terdakwa pada sekitar bulan Maret 2016 sampai dengan Oktober 2016 atau setidak-tidaknya pada suatu waktu lain dalam tahun 2016 atau bertempat di Warkop Onta 77 Jalan Onta Lama kota Makassar atau Jalan Tun Abdul Razak Kompleks Ruko Citraland Blok L/22 tempat terdakwa ditahan dimana daerah tersebut masih wilayah hukum daerah Makassar, lalu saksi dan korban dikumpulkan pada saat itu.

2. Keterangan terdakwa

Keterangan terdakwa menurut KUHAP Pasal 184 butir e, digolongkan sebagai alat bukti. Keterangan terdakwa adalah apa yang dinyatakan terdakwa di sidang tentang perbuatan yang ia lakukan atau yang ia ketahui sendiri atau dialami sendiri. Menurut Mohd. Din, dalam praktik keterangan terdakwa sering dinyatakan dalam bentuk pengakuan atau penolakan, baik sebagian maupun keseluruhan terhadap dakwaan penuntut umum dan keterangan yang disampaikan oleh para saksi. Keterangan terdakwa sekaligus juga merupakan jawaban atas pertanyaan baik yang diajukan oleh penuntut umum, hakim maupun penasihat hukum. Keterangan terdakwa yang diajukan di muka sidang pada umumnya merupakan jawaban atas pertanyaan yang diajukan oleh hakim ataupun penuntut umum. ${ }^{12}$ Berikut ini akan dikemukakan pertimbangan hakim berkaitan dengan keterangan terdakwa yang disampaikan di dalam sidang yaitu yang terdapat dalam putusan nomor 222/Pid.Sus /2018/Pn.Mks.

Menimbang bahwa di awal persidangan telah didengar pula keterangan dari terdakwa, yang pokoknya menerangkan diantaranya:

a. bahwa dakwaan penuntut umum tersebut telah benar

b. bahwa terdakwa menghimpun dana dari masyarakat dalam bentuk simpanan (giro, deposito, tabungan, atau bentuk lain yang disamakan)

c. bahwa terdakwa menghubungi saksi untuk ke kendari melihat sistem trading binary.com dengan menggunakan robot lucky like. Sehingga terdakwa memiliki ide membuat komunitas trader yang bernama profitwin 77.

d. Bahwa cara alur masuk dan keluar profitwin77 adalah uang yang masuk ke rekening saksi yaitu menggunakan bank Mandiri, BNI, BCA dan semua uang yang keluar diindustrikan langsung oleh terdakwa.

e. Bahwa pola trader diperintahkan oleh terdakwa yaitu trader akan melakuan tradingan menggunakan robot jika sudah ada saldo dalam akun binary.com yang disodorkan oleh terdakwa, jumlah yang ditransfer sebesar $30 \%$ dari dana setiap member untuk ditradingkan dan $70 \%$ alokasi pembagian, serta $2 \%$ perhari termasuk bonus.

\footnotetext{
${ }^{11}$ Republik Indonesia, Undang-Undang Nomor 10 Tahun 1998 tentang perubahan atas UndangUndang Nomor 7 Tahun 1992 tentang perbankan (t.d), h..24.

${ }^{12}$ Rika Mona Pandengirot, SH,MH, Hakim Pengadilan Negeri Makassar, Wawancara, 24 Mei 2019.
} 
f. Bahwa cara terdakwa menghimpun dana masyarakat adalah dengan memperlihatkan system aplikasi dalam bentuk website profitwin77 dengan mengiming-imingkan bagi hasil setelah gabung 100 hari dengan mendapat keuntungan $2 \%$ dengan rincian $1 \%$ pokok $+1 \%$ bunga.

g. Bahwa terdakwa menghimpun dana dari masyarakat secara tunai dan non tunai menggunakan Mandiri, BCA, BNI, dan Bank Maybank.

h. Bahwa perbuatan terdakwa membuat banyak member mengalami kerugian.

3. Barang Bukti

Meskipun barang bukti bukan sebagai alat bukti, namun apabila penuntut umum menyebutkan barang bukti itu didalam surat dakwaannya, kemudian mengajukannya barang bukti itu kepada hakim, hakim ketua dalam pemeriksaan harus memperlihatkannya, baik kepada terdakwa, maupun kepada saksi, bahkan kalau perlu hakim membuktikannya dengan membacakan atau memperlihatkan surat atau berita acara kepada terdakwa atau saksi dan selanjutnya minta keterangan seperlunya. Dalam putusan perkara Nomor 222/Pid.Sus/2018/Pn.Mksbarang bukti yang diajukan oleh jaksa penuntut umum sebagai berikut:

a. Buku tabungan BCA KCU Makassar No. Rek. 0255202575 a.n Arsyad,

b. Rekening Koran BCA KCU Makassar No. Rek. 0255202575 a.n Arsyad,

c. Formulir pembukaan rekeing perorangan tanggal 22 Juli 20164555836616 a.n Arsyad,

d. Buku tabungan BNI KCP Sam Ratulangi No.Rek 4555836616 a.n Arsyad;

e. Buku tabungan Mandiri KC Makassar Kartini No. Rek. 1520013325648 a.n Arsyad,

f. Buku tabungan Bank Maybank KCP Panakukang Makassar No.Rek 1150002429 a.n Arsyad,

g. Rekening koran BNI nomor rekening 0458819994 a.n Wiwing Mustafa,

h. Rekening Koran BNI nomor rekening 0470175724 a.n Musliadi,

i. Satu rangkap profil data Lk. Musliadi selaku member profitwin77,

j. Satu rangkap profil data Lk. Sudarman selaku member profitwin77,

k. Satu rangkap profil data Lk. Wahidu selaku member profitwin77,

1. Satu rangkap profil data Lk. Wiwing Mustafa selaku member profitwin77.

2. Pandangan Hukum Islam tentang Pendirian Bank Tanpa Izin Berdasarkan Perbankan Syariah pada Kasus 222/Pid.Sus/2018/PN.Mks.

Perbankan syariah kini telah popular dan banyak diminati oleh sejumlah masyarakat terutama yang beragama Islam karena perbankan syariah itu sendiri dianggap perbankan yang aman tanpa riba sehingga dewasa ini banyak yang berlomba-lomba pindah ke bank syariah. Bank syariah itu sendiri sebenarnya sama saja dengan bank konvensional hanya saja produk bank syariah dibuat sedemkian rupa sehingga bisa menarik perhatian atau menyita masyarakat muslim untuk mengikuti syariat Islam supaya tidak lagi terlibat dengan masalah riba. Bank syariah juga termasuk bank yang mudah dijangkau, murah dan biasanya tidak memotong saldo nasabah bank syariah.

Maraknya shadow banking menjadi permasalahan mendasar adalah kurangnya pemahaman masyarakat tentang produk-produk jasa keuangan berbasis syariah. Kurangnya sosialisasi kepada masyarakat membuat shadow banking malah semakin merusak perekonomian negara sehingga sosialisasi dan edukasi masyarakat begitu penting karena masalah shadow banking bahkan mempengaruhi bank syariah sehingga 
para nasabah berani berinvestasi melalui trading yang sudah banyak mempengaruhi pasar perbankan meskipun sudah berbasis syariah.

Banyak pelaku usaha trading tidak berani menggunakan rekening bank syariah secara ilegal karena pelaku usaha tersebut hanya memakai bank konvensional sehingga kasus yang telah terjadi hanya menggunakan bank konvnsional. ${ }^{13}$

Shadow banking berakitan dengan masalah muamalah yang telah diatur di dalam fiqih sehingga muamalah dibolehkan jika tidak mengandung zat-zat yang haram yang dapat merugikan jiwa, pikiran, dan keturunan. Shadow banking itu sendiri seharusnya tidak dilakukan karena melanggar muamalah yang zatnya harus halal meskipun pelaku telah menadakan akad kepada nasabah tetapi pelaku telah melakukan kebohongan dengan cara mengiming-imingkan kepada nasabah untuk meraih keuntungan $2 \%$ dari investasi nasabah selain zatnya yang haram, shadow banking juga telah termsuk riba karena mendapatkan keuntungan yang asalnya dari uang nasabah yang lain artinya nasabah $\mathrm{A}$ dan nasabah $\mathrm{B}$ tidak mengtahui jika keuntungan tersebut dari nasabah yang lain. Investasi nasabah tidak bertambah dari penghasilan tertentu misalnya si A berinvestasi di pabrik gula sebesar $100 \%$ guna mendapatkan keuntungan $50 \%$ dari penjualan gula tersebut tetapi investasi pada trading tidaklah jelas keuntungannya didaapatkan dari mana jadi hal tersebut dinggap riba. Tetapi shadow banking memang termasuk syirkah karena nasabah berinvestasi telah diawali dengan akad artinya ivestor setuju sehingga terjadilah perkongsian dana dari investor. Ulama juga sepakat bahwa syirkah dibolehkan jika zatnya tidak haram, zatnya jelas tetapi syirkah tidak akan dibolehkan meskipun ada ijab dan qobul antara pelaku dan investor. Meskipun shadow banking tidak dijelaskan langsung di dalam hadis dan Al-Quran tetapi unsur shadow banking berkaitan dengan syirkah.

Firman Allah dalam surat QA Al-Ma'idah ayat /5:2:

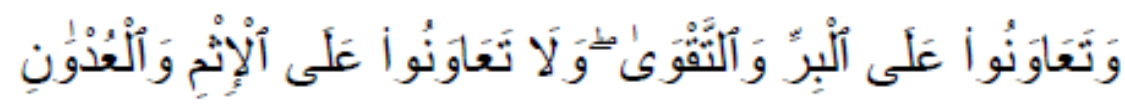

Terjemahannya:

“...Dan tolong-menolonglah kamu dalam (mengerjakan)kebajikan dan takwa, dan jangan tolong-menolong dalam berbuat dosa dan pelanggaran..."

Pendirian bank tanpa izin (shadow banking) termasuk jarimah tazir hal tersebut telah ditetapkan oleh pemerintah, namun di dalam hukum Islam pendirian bank tanpa izin/menghimpun dana masyarakat tanpa izin termasuk penipuan karena meraup keuntungan dana masyarakat dengan iming-iming keuntungan yang besar melaui sistem aplikasi. Selain penipuan zat yang terkadung di dalam shadow banking tidaklah halal sehingga syirkah menjadi tidak sah, seperti yang peneliti jelaskan syirkah termasuk haram dan mengandung riba meskipun syirkah termasuk perbuatan yang baik karena bersifat saling tolong menolong untuk mendapatkan harta atau untuk memperkaya diri tetapi ada unsur haram di dalamnya sehingga syirkah bisa menjadi batal. Syirkah salah satu bentuk kerja sama yang menguntungkan satu sama lain sehingga hal tersebut dibolehkan oleh ulama dan telah diatur dalam kaidah fiqih, untuk mencapai keuntungan bersama secara halal dan mudah dijangkau maka terjadilah perkongsian dana untuk mendapatkan laba. Pendirian bank tanpa izin (shadow banking) termasuk jarimah tazir

${ }^{13}$ Aris Gunawan S.H, M.H, Hakim Pengadilan Negeri Makassar, Wawancara, Makassar, 21 Mei 2019. 
hal tersebut telah ditetapkan oleh pemerintah namun di dalam hukum Islam pendirian bank tanpa izin menghimpun dana masyarakat tanpa izin termasuk penipuan karena meraup keuntungan dana masyarakat dengan iming-iming keuntungan yang besar melalui sistem aplikasi yang disebut trading. Trading juga termasuk wadah investasi yang tidak halal zatnya.

Adapun pandangan hukum Islam yang berkaitan dengan putusan nomor 222/Pid.sus/2018/Pn.Mks adalah sebagai berikut:

1. Haram zatnya , seperti babi, khamar, bangkai, atau darah. Karena haramnya zat dapat mengganggu jiwa, keturunan dan harta. Sehingga jiwa tidak tenang dan bisa saja keturunan memakan harta yang zatnya haram.

2. Haram selain zatnya karena syirkah akan menjadi haram sebab mengadung riba.

3. Tidak sah (lengkap) akadnya, seperti tidak terpenuhinya rukun dan syarat, terjadi ta'alluq, karena shadow banking tidak memiliki izin oleh pihak Bank.

4. Syirkah akan batal dengan sendirinya apabila rusaknya harta Syirkah, baik sebagian atau seluruhnya, rusaknya harta syirkah dikarenakan ada unsur penipuan sehingga modal tersebut bisa saja lenyap. Jika modal tersebut lenyap sebelum terjadi percampuran harta hingga tidak dapat dipisahkan lagi maka yang menanggung resiko adalah pemeliknya sendiri, apabila harta sudah lenyap (kecuali perbuatan bersama) setelah percampuran dan tidak dapat dipisah lagi maka hal tersebut menjadi tanggungan bersama.

5. Syirkah juga akan berakhir apabila salah satu pihak bangkrut yang berakibat tidak berkuasa atas harta yang menjadi saham syirkah maka syirkah bisa berakhir atau batal dengan sendirinya.

6. Termasuk Syirkah Amwāl (Kongsi Modal) karena terjadi percampuran dana dan bagi hasil hal tersebut dibolehkan tetapi hal tersebut bisa menjadi tidak sah (lengkap) akadnya karena belum / tidak memiliki izin dari pihak bank.

\section{KESIMPULAN}

Berdasarkan pembahasan diatas, penulis mengambil kesimpulan:

1. Bahwa penerapan hukum pidana pada kasus Nomor 222/Pid.Sus/2018/Pn.Mks yaitu terdakwa dinyatakan telah melanggar Pasal 46 ayat 1 Jo. Pasal 16 Undang-Undang Nomor 7 Tahun 1992 tentang perbankan, bahwa terdakwa telah terbukti secara sah dan menyakinkan bersalah melakukan tindak pidana tanpa izin melakukan usaha perbankan, bahwa terdakwa telah dijatuhkan pidana penjara selama 5 tahun dan denda sebesar 10.000.000.00 (sepuluh miliar rupiah), jika tidak dibayarkan maka akan diganti dengan penjara selama 6 bulan, bahwa terdakwa terbukti dengan barang bukti berupa rekening tabungan BCA, Mandiri, BNI, dan Maybank.

2. Pertimbangan hakim yang bersifat yuridis berdasarkan fakta-fakta yuridis yang terungkap didalam persidangan dan Undang-Undang yang harus dimuat didalam putusan adapun pertimbangan hakim yang digolongkan sebagai pertimbangan yuridis yaitu antara lain: dakwaan jaksa penuntut umum, keterangan terdakwa, dan barang bukti. Hukum Islam berapandangan bahwa shadow banking merupakan sesuatu yang ilegal sehingga hal tersebut menjadi haram dan tidak sah (lengkap) akadnya, seperti tidak terpenuhinya rukun dan syarat, terjadi ta'alluq, karena shadow banking tidak memiliki izin oleh pihak Bank. Shadow Banking juga menjadi batal (gharar). 


\section{DAFTAR PUSTAKA}

Adriyanto. Peran Penyaluran Kredit Non Perbankan dan Pertumbuhan Ekonomi: Persfektif dari Negara Emerging G20. Jakarta: Badan Kebijakan Fiskal Kememkeu, 2013.

Alsuhendi, Hendi. Fiqh Muamalah. Jakarta: Raja Grafindo Persada, 2008.

Bambang, Sutisyo. Metode Penemuan Hukum, Yogyakarta: UII Press, 2006.

Dewi, Gemala. Aspek-aspek Hukum dalam Perbankan \& Perasuransian Syariah di Indonesia. Jakarta: Kencana, 2017.

Edriyanto Efendi, Hukum Pidana Indonesia. Bandung: Refika Aditama, 2011.

Gernasih, Yenti. Penegakan Hukum Anti Pencucian Uang dan Permasalahannya di Indonesia. Depok: Rajawali Pers, 2017.

Gufron, A. Mas'adi. Fiqh Muamalah. Jakarta: Rajawali Pers, 2002.

Hamzah, Andi. Hukum Acara Pidana Indonesia. Jakarta: Sinar Grafika, 2008.

Junaidi. Pengaturan Hukum Perbankan Syari'ah di Indonesia. Malang: UIN-Malang Press, 2009.

Kementerian Agama RI. Al-Qur'an dan terjemahnya. Jakarta: Dharma art, 2014.

Lina, Desi, Oktaviani Suendra. Pertanggung Jawaban Pidana Koperasi dalam Tindak Pidana Melakukan Perbankan Tanpa Ijin, Magister Hukum Udayana, Vol. 4, No.2.

Nasir, Moh. Metode Penelitian. Bogor: Ghalia Indonesia, 2005.

Noor, Juliansyah. Metodologi Penelitian: Skripsi,Tesis, Desirtasi, \& Karya Ilmiah. Jakarta: Kencana, 2011.

Rodliyah, dan Salim H.s. Hukum Pidana Khusus Unsur dan Sanksi Pidananya Depok: Rajawali Pers, 2017.

Saputro, Darmono dan Siswandi, Banking and Non Banking. Jakarta: Lentera Ilmu Cendikia, 2010.

Soekanto, Soerjono. Pengantar Penelitian Hukum. Jakarta: UI Press, 1986.

Soekanto, Soerjono dan Sri Mamuji. Penelitian Hukum Normatif. Jakarta: Rajawali, 1985.

Sudarto. Kapita Selekta Hukum Pidana. Bandung: Alumni, 1986.

Sugiyono. Metode Kuantitatif, Kualitatif dan R \& D. Bandung: Alfabet, 2009.

Sukardi. Metodologi Penelitain Kompetensi dan Prakteknya. Jakarta: Bumi Aksara, 2007.

Universitas Islam Negeri Alauddin Makassar. Pedoman Penulisan Karya Tulis Ilmiah:

Makalah, Skripsi, Tesis, Disertasi dan Laporan Penelitian. Makassar: Alauddin Press, 2013.

Utami, Wahyu dan Yogabakti Adipradana. Pengantar Hukum Bisnis dalam Persfektif Teori dan Praktiknya di Indonesia. Jakarta: Jala Permata Aksara, 2017.

Az-Zuhaili, Wahabah Fiqih Islam Wa Adilllatuhu jilid 5 Jakarta: Gema Insani, 2011. 